\title{
Jacobaea taurica (Asteraceae), the new combination for a Crimean protected species
}

\author{
Sergiy L. MOSYAKIN ${ }^{1 *}$, Andriy V. YENA² \\ ${ }^{1}$ M.G. Kholodny Institute of Botany, National Academy of Sciences of Ukraine \\ 2 Tereschenkivska Str., Kyiv 01004, Ukraine \\ s_mosyakin@hotmail.com \\ ${ }^{2}$ The Committee for Mapping the Flora of Europe \& Ukrainian Botanical Society \\ *Author for correspondence
}

Mosyakin S.L., Yena A.V. Jacobaea taurica (Asteraceae), the new combination for a Crimean protected species. Ukr. Bot. J., 2017, 74(4): 303-309.

\begin{abstract}
Senecio tauricus (Asteraceae) was described as an endemic species restricted to the mountain plateaus (yailas) of the Crimean Peninsula, growing only in meadow-steppe plant communities. The species status for this taxon was accepted in all relevant floras, identification manuals, and checklists; it is also listed in the current edition of the Red Data Book of Ukraine (2009) and some other lists of protected plant species. Following the results of recent molecular phylogenetic studies that justified the segregation of several genera housing taxa earlier placed in Senecio sensu lato, the new nomenclatural combination Jacobaea taurica is proposed. Basic information on morphology, ecology and distribution of J. taurica and related taxa is also briefly discussed and summarized.
\end{abstract}

Keywords: Senecio, Jacobaea, Asteraceae, nomenclature, taxonomy, Crimea, endemic species

\section{Introduction}

There are four species of Senecio L. [S. glaucus L. subsp. coronopifolius (Maire) C. Alexander, S. leucanthemifolius Poir. subsp. vernalis (Waldst. \& Kit.) Greuter, S. tauricus Konechn., S. vulgaris L.] and four species of Jacobaea Mill. [J. borysthenica (DC.) B. Nord. \& Greuter; J. erucifolia (L.) G. Gaertn., B. Mey. \& Scherb. (incl. subsp. arenaria (Soó) B. Nord. \& Greuter and subsp. erucifolia), J. vulgaris Gaertn., and J. maritima (L.) Pelser \& Meijden subsp. maritima] currently reported for and taxonomically recognized in the Crimean Peninsula (Yena, 2012). However, one of these taxa, Senecio tauricus Konechn. (Konechnaya, 1985: 230), in fact belongs to the species aggregate of Jacobaea vulgaris Gaertn. (= Senecio jacobaea L.), which embraces also several other species, such as $J$. ambracea (Turcz. ex DC.) B. Nord., J. andrzejowskyi (Tzvelev) B. Nord. \& Greuter, J. borysthenica (DC.) B. Nord. \& Greuter, and J. ferganensis (Schischk.) B. Nord. \& Greuter. The Crimean taxon currently known as $S$. tauricus appears

(C) S.L. MOSYAKIN, A.V. YENA, 2017 to be nomenclaturally "neglected", even after the recent restoration of Jacobaea, now recognized as a genus phylogenetically distinct from Senecio (Pelser et al., 2002, 2007, 2010; Nordenstam, 2006; Nordenstam et al., 2009). There are several possible reasons for this "negligence": (1) the phytogeographical status of the taxon as a little-known local endemic of Crimea; (2) the lack of its specimens in major herbaria, especially those collected by local botanists, and (3), the lack of relevant sources on the Crimean plants published in languages other than Russian and Ukrainian (see e.g. Cordova, 2015). Here we provide information currently available on this taxon and propose its formal transfer to Jacobaea.

\section{Phylogenetic distinctiveness of Jacobaea}

Recent molecular phylogenetic studies of Senecio and related taxa (Pelser et al., 2002, 2007, 2010, etc.; see also an overviews in Nordestam et al., 2009 and Kadereit et al., 2016) justified the segregation of several genera, including Jacobaea, housing taxa earlier placed in Senecio sensu lato. For most of these taxa, new 
combinations or names in the currently recognized genera either were available earlier or have been validated recently. In particular, new combinations for taxa transferred to Jacobaea and other segregates of Senecio have been proposed by Pelser et al. (2006), and then Nordenstam (2006) and Nordenstam and Greuter (in Greuter, Raab-Straube, 2006, 2007) in the course of preparation of the treatment of Asteraceae for the Euro+Med PlantBase Project (Greuter, 2006-onward; Greuter, Raab-Straube, 2008). Totally more than 90 new combinations in Jacobaea were published for species and infraspecific taxa since 2006 (IPNI, 2017onward). However, no transfer of Senecio tauricus (at any rank) to Jacobaea has been proposed yet, and the species is still recognized in Senecio in the Euro+Med PlantBase (Greuter, 2006-onward) and The Plant List (2013-onward), as well as in recent basic reference publications covering the flora of Crimea (Yena, 2009, 2012; Rudenko, 2016, etc.).

\section{Taxonomic history of Senecio tauricus}

In Flora Taurica (Privalova, 1969), there was only a note under Senecio jacobaea with some considerations regarding peculiarities of the plants from the Crimean treeless mountain plateaus locally called yailas (yaila in singular; derived from the Crimean Tatar [Q1rımtatar] language, meaning summer pasture or summer rangeland; also jaila or yayla in some other Turkic languages): "Plants from the yaila are often of stocky habit, with large heads and long ray florets that are twice as long as the involucre" (Privalova, 1969: 228; in Russian: "Яйлинские растения часто имеют более приземистый рост, крупные корзинки и длинные язычковые цветы, вдвое превышающие длину обертки").

Konechnaya (1985) later described those plants as Senecio tauricus, an endemic species restricted to the Crimean Mountains. According to the protologue, this species differs from $S$. jacobaea (now Jacobaea vulgaris) in having lower height, lesser number of heads (capitulae) within the terminal corymb, and noticeably larger heads, longer ray florets and involucral bracts. It was also compared in the protologue with $S$. ambraceus Turcz. ex DC. (Candolle, 1838: 348; now Jacobaea ambracea (Turcz. ex DC.) B. Nord.: Nordenstam, 2006: 13) known to occur mainly in southeastern Siberia, the Russian Far East (south), Mongolia, northern China, and Korea (Chen et al., 2011; Zuyev, 2012), from which the Crimean species was reported to differ in a lesser number of ray florets and of inner involucral bracts ("13, not 21", as given in the protologue).

Following its description in $1985, S$. tauricus was accepted as a distinct species in all relevant floras, identification manuals, and checklists covering plants of Ukraine and Eastern Europe in general (Katina, 1987; Konechnaya, 1994; Mosyakin, Fedoronchuk, 1999; Yena, 2012). In his analysis of endemism of the Crimean flora, Yena (2001, 2008, 2012) also accepted this species and recognized it as a local endemic of the Crimean Peninsula.

\section{Ecology of Senecio tauricus}

Senecio tauricus seems to be geographically and ecologically restricted to meadow and meadow-steppe plant communities of the treeless plateaus (yailas) of the Crimean Mountains (see distribution maps and associated information in Yena, 2009; Rudenko, 2015), while Jacobaea vulgaris (= Senecio jacobaea) occurs in a much wider range of open habitats throughout the Crimean Peninsula, including steppe, flatland and foothill meadows, and ruderal plant communities. Judging from available herbarium specimens and field observations, J. vulgaris occurs on yailas very rarely, more likely accidentally due to human activities (transport, tourism etc.). It should be also noted that yaila areas are the most endemic-rich habitats of Crimea, with more than $50 \%$ of the currently recognized ca. 106 Crimean endemic vascular plant species occurring here (Yena, 2008). The high diversity of endemic plants in these habitats is partly explained by the diverse altitudes and complexity of landscapes therein, as well as by the complex patterns of geological and biogeographic history of the Crimean region (for further details see Yena, 2008, 2012; Cordova, 2015 and references therein).

According to the new classification proposed for habitats of the Crimean Mountains (Didukh et al., 2016), the actual and expected habitats of $S$. tauricus belong to the following categories and subcategories: E1.25 Crimean meadows (E1.251 Meadows on deforested areas, and E1.252 Meadow biotopes on yaila karst funnels) and E2.15 Mountain meadow steppe biotopes (E2.1512 Biotopes of mountain sod meadowsteppes on well developed chernozems of highland yailas). According to the EUNIS Habitat Classification (European Environment Agency, 2014-onward; Didukh et al., 2016; Onyshchenko, 2016), such habitats mainly belong to the category E2.251: Ponto-Pannonic mesophile hay meadows. 


\section{Morphology of the species, with considerations of its relationships}

Judging from morphological characters of plants from the Crimean Mountains, they are indeed closely related to Jacobaea vulgaris, differing from the latter mainly in some quantitative characters, particularly those mentioned in the protologue (see above). As a result of examining numerous specimens of this and related species available in $K W$ and $C S A U$ (herbarium acronyms following Thiers, 2017-onward), we can additionally note that $S$. tauricus also differs from $J$. vulgaris in having rosettes more persistent at maturity, glabrous (almost totally hairless) leaves, wider ray florets, and especially well-developed black widely triangular marks on the tips of inner involucral bracts (in Crimean plants of $J$. vulgaris sensu stricto these black marks are narrowly triangular, hatched, or nearly absent).

Several good field photographs of $S$. tauricus (including close-ups) are available from the Plantarium web site (http://www.plantarium.ru/page/view/item/ 35275.html). Two of these images (photographs by Ilya Turbanov) represent plants identified by Galina Yu. Konechnaya, the author of the species (http://www. plantarium.ru/page/image/id/25994.html;http://www. plantarium.ru/page/image/id/25995.html).

It was convincingly demonstrated recently that $J$. vulgaris is a morphologically and karyologically diverse and variable species (or species aggregate) represented by several cytotypes (ranging from diploids to octoploids, with occasional presence of some aneuploids) and weakly delimited morphotypes, now often treated as subspecies and/or varieties (Wysk et al., 2009; Hodálová et al., 2010, 2015; Conti et al., 2012; Mered'a et al., 2016a, b). Some ecological preferences of these entities were also reported, but their geographical ranges remain insufficiently known (Mered'a et al., 2016a, b). These studies already indicated that octoploids and hexaploids tend to have (among other characters) somewhat longer ray florets, involucral bracts and tubular florets, as compared to the tetraploid cytotype of $J$. vulgaris (Hodálová et al., 2015; Mered'a et al., 2016b). Rather long ray florets and involucral bracts are also peculiar to the Crimean montane plants, which may suggest their higher ploidy level(s). However, no ploidy information is available yet for these Crimean plants.

No synonyms or infraspecific entities have been reported or validated so far for $S$. tauricus. It also has been not yet treated as an infraspecific taxon of any other species. Judging from the information available from the cited and some other references and from selected herbarium specimens (consulted mainly in $C S A U$ and $K W$ ), we were unable to establish possible identity of the Crimean plants with any currently recognized infraspecific taxon of $J$. vulgaris or related species occurring in the neighboring regions (mainland Ukraine, SW European Russia, Central Europe, the Caucasus, the Balkans, etc.). In terms of their gross morphology and especially habit, the stout but rather low-growing Crimean yaila plants are evidently different from typical forms of the tetraploid subspecies (Jacobaea vulgaris subsp. vulgaris) and also from octoploid subspecies [J. vulgaris subsp. gotlandica (Neuman) B. Nord. and J. vulgaris subsp. pannonica Hodálová \& Mered'a]. The identity of $J$. vulgaris diploids remains taxonomically unresolved (Mered'a et al., 2016b). Crimean plants from yailas also differ from predominantly psammophytic taxa Jacobaea borysthenica (DC.) B. Nord. \& Greuter (= Senecio borysthenicus (DC.) Andrz. ex Czern., S. praealtus Bertol. var. borysthenicus DC.) and J. andrzejowskyi (Tzvelev) B. Nord. \& Greuter (S. andrzejowskyi Tzvelev) occurring mainly along large rivers of Eastern Europe (Tzvelev, 1986; Konechnaya, 1994; Greuter, RaabStraube, 2006).

Thus, at present we prefer to maintain $S$. tauricus as a separate species of Jacobaea, pending further research. Additional comparative morphological, karyological, and molecular phylogenetic studies are needed for identifying the precise phylogenetic position, origin, and the best-suitable taxonomic rank of the Crimean montane plants related to J. vulgaris and accepted in recent literature as $S$. tauricus. We hope that this nomenclatural note will attract attention of researchers to this still poorly known taxon and will stimulate its much-needed further detailed studies in comparison with other taxa of the $J$. vulgaris aggregate.

\section{Conservation status of Senecio tauricus}

Senecio tauricus is listed in the $3^{\text {rd }}$ (current) edition of the Red Data Book of Ukraine (Yena, 2009) with the conservation status "Rare"; it is also included in some other regional "red lists" (List..., 2013; Rudenko, 2015; the first list is part of the Ukrainian legislation; the second list has no legal status in Ukraine). The reported main threat factors for that species are its narrow 


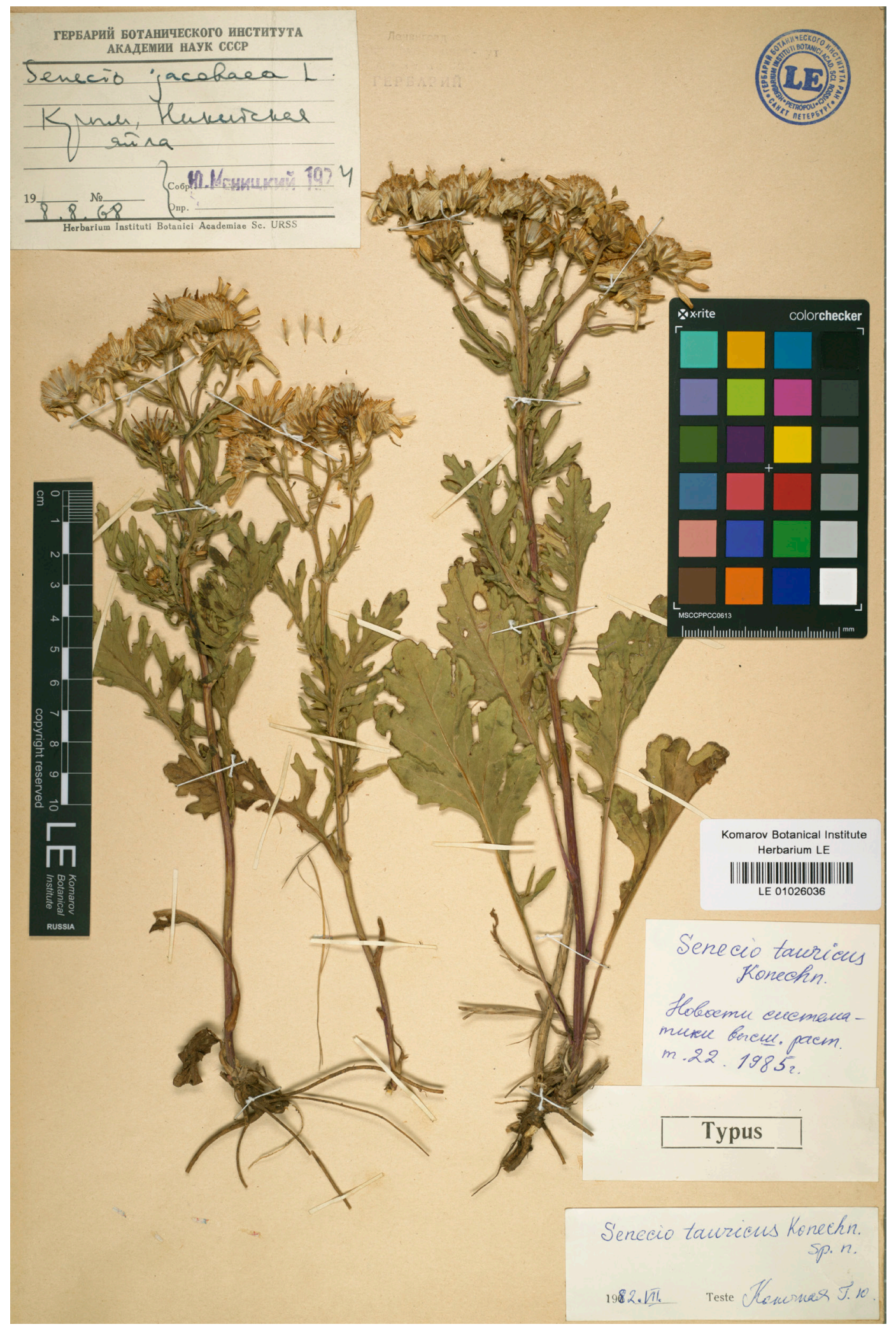

Holotype of Senecio tauricus Konechn. (LE01026036), now accepted as Jacobaea taurica (Konechn.) Mosyakin \& Yena 
ecological niche, afforestation of yailas, local livestock grazing, recreation, and potentially also climate changes that may result in aridification and transformation of yaila meadow-steppe plant communities. No special populational studies of the species have been performed so far; thus, data on its populations are scarce.

\section{Validation of the new nomenclatural combination}

Considering the evident position of $S$. tauricus within the genus Jacobaea (in or near the $J$. vulgaris species aggregate), its morphological distinctiveness and partial geographical isolation, as well as the conservational importance and protected status of this taxon, a new combination is needed, which is validated below.

Jacobaea taurica (Konechn.) Mosyakin \& Yena, comb. nov.

Basionym: Senecio tauricus Konechn. 1985, Novitates Systematicae Plantarum Vascularium 22: 230 (Konechnaya, 1985: 230).

Type (holotype, $L E$, Figure 1): UKRAINE [Crimean Region - Кримська область, according to the administrative subdivision actual in 1968 and 1985]. "Tauria, jailla Nikitiensis, 8 VIII 1968, Yu. Menitsky" [Original label in Russian: "Senecio jacobaea L. Крым, Никитская яйла, 8. 8. 1968, Ю.[Л.] Меницкий"; annotation label: "Senecio tauricus Konechn. sp. n. 1982.VII. Teste Конечная Г.Ю."] (LE01026036 - digital image!).

\section{Acknowledgments}

The authors express their sincere gratitude to Prof. Karol Marhold, Dr. Iva Hodálová and Dr. Pavol Mered'a Jr. (Botanický ústav SAV / Institute of Botany, Slovak Academy of Sciences, Bratislava, Slovakia) for their useful comments on the manuscript and productive discussion; to Prof. Yakiv P. Didukh (M.G. Kholodny Institute of Botany, National Academy of Sciences of Ukraine, Kyiv, Ukraine) for discussing ecological peculiarities of the species; to Dr. Ivan V. Tatanov (V.L. Komarov Botanical Institute, Russian Academy of Sciences, St. Petersburg, Russia) for providing the digital image of the holotype from LE; and to Dr. Dmitry V. Geltman (Director, Komarov Botanical Institute) for authorizing us to use that image in the article. An earlier version of the present article was submitted to Phytotaxa, and one anonymous reviewer provided several useful suggestions, which are gratefully acknowledged.

\section{REFERENCES}

Candolle A.P. de. Prodromus systematis naturalis regni vegetabilis. Parisiis [Paris]: Sumptibus Sociorum Treuttel et Würtz, "1837" (published 1838), vol. 6, 687 pp.

Chen Y.L., Nordenstam B., Jeffrey C., Vincent L. Senecio. In: Flora of China. Eds Z.Y. Wu, P.H. Raven, Beijing: Science Press; St. Louis: Missouri Bot. Garden Press, 2011, vol. 20-21, pp. 508-536.

Conti F., Bartolucci F., Tomović G., Lakušić D. Jacobaea vulgaris subsp. gotlandica (Compositae), new for Italy and Montenegro. Bot. Serbica, 2012, 36(2): 145-147.

Cordova C. Crimea and the Black Sea: An Environmental History (Environmental Historical and Global Change: 7), London; New York: I.B. Tauris \& Co. Ltd, 2015, 235 pp.

Didukh Ya.P., Fitsailo T.V., Mala Yu.I., Pashkevych N.A., Khodosovtsev O.E. Biotopes of the Crimean Mountains, Kyiv: NVP Interservice, 2016, 292 рр. [Дідух Я.П., Фіцайло Т.В., Мала Ю.І., Пашкевич Н.А., Ходосовцев О.Є. Біотопи Гірського Криму, Київ: НВП Інтерсервіс, 2016, 292 c.].

European Environment Agency. EUNIS Habitat Classification (2014-onward). Published 26 May 2014. Last modified 10 Mar 2016, available at: http://www.eea. europa.eu/themes/biodiversity/eunis/eunis-habitatclassification (accessed 13 March 2017).

Greuter W. Compositae (pro parte majore). In: Greuter W., von Raab-Straube E. (Eds), Compositae. Euro+Med PlantBase - the information resource for Euro-Mediterranean plant diversity (2006-onward), available at: http://ww2.bgbm.org/EuroPlusMed/ PTaxonDetail.asp? Name Cache $=$ Senecio $\% 20$ tauricus\&PTRefFk=7000000 (accessed 16 February and 13 March 2017).

Greuter W., von Raab-Straube E. (Eds), Euro+Med Notulae, 2. Willdenowia, 2006, 36: 707-717. doi:10.3372/wi.36.36206

Greuter W., von Raab-Straube E. (Eds). Euro+Med Notulae, 3 [Notulae ad floram euro-mediterraneam pertinentes 25]. Willdenowia, 2007, 37: 139-189. doi:10.3372/wi.37.37107

Greuter W., von Raab-Straube E. (Eds). Med-Checklist: A critical inventory of vascular plants of the circumMediterranean countries. Palermo: OPTIMA Secretariat; Genève: Med-Checklist Trust of OPTIMA; Berlin: Euro+Med PlantBase Secretariat, 2008, vol. 2, cclxxxviii $+798 \mathrm{pp}$.

Hodálová I., Mered'a P. Jun., Vinikarová A., Grulich V., Rotreklová O. A new cytotype of Jacobaea vulgaris (Asteraceae): frequency, morphology and origin. Nordic J. Bot., 2010, 28(4): 413-427. doi: 10.1111/j.1756-1051.2010.00603.x

Hodálová I., Mered’a P. Jr., Kučera J., Marhold K., Kempa M., Olšavská K., Slovák M. Origin and systematic position of Jacobaea vulgaris (Asteraceae) octoploids: genetic and morphological evidence. Plant Syst. Evol., 2015, 301: 1517-1541.

IPNI. The International Plant Names Index (2017-onward). Published on the Internet: http://www.ipni.org (accessed 16 February 2017). 
Kadereit J.W., Albach D.C., Ehrendorfer F., GalbanyCasals M., Garcia-Jacas N., Gehrke B., Kadereit G., Kilian N., Klein J.T., Koch M.A., Kropf M., Oberprieler C., Pirie M.D., Ritz C.M., Röser M., Spalik K., Susanna A., Weigend M., Welk E., Wesche K., Zhang L.-B., Dillenberger M.S. Which changes are needed to render all genera of the German flora monophyletic? Willdenowia, 2016, 46: 39-91. doi: http://dx.doi. org/10.3372/wi.46.46105

Katina Z.F. Senecio. In: Identification manual of vascular plants of Ukraine. Ed. Yu.N. Prokudin, Kiev: Naukova Dumka, 1987, pp. 343-346. [Катина 3.Ф. Senесіо. В кн.: Определитель высших растений Украины. Ред. Ю.Н. Прокудин, Киев: Наук. думка, 1987 , с. 343-346.]

Konechnaya G.Yu. Generis Senecio L. (Asteraceae) species nova e Tauria. In: Novitates Systematicae Plantarum Vascularium, Leningrad: Nauka, 1985, vol. 22, pp. 230-231. [Конечная Г.Ю. Новый вид рода Senecio L. (Asteraсеае) из Крыма. В кн.: Новости системат. высш. pacm., Л.: Наука, 1985, т. 22, с. 230-231.]

Konechnaya G.Yu. Senecio. In: Flora Partis Europaeae URSS. Ed. N.N. Tzvelev, St. Petersburg: Nauka, 1994, vol. 7, pp. 52-63. [Конечная Г.Ю. Senecio. В кн.: Флора европейской части СССР. Ред. Н.Н. Цвелев, СПб: Наука, 1994, т. 7, с. 52-63.]

List of plant species under special protection in the territory of the Autonomous Republic of Crimea. 2013. Annex 1 to Decree of the Supreme Council of the Autonomous Republic of Crimea of 21.06.2013 No. 1323-6/13 "On plant species under special protection in the territory of the Autonomous Republic of Crimea" [Перелік видів рослин, що підлягають особливій охороні на території Автономної Республіки Крим. 2013. Додаток 1 до Постанови Верховної Ради Автономної Республіки Крим від 21.06.2013 р. №1323-6/13 "Про види рослин, що підлягають особливій охороні на території Автономної Республіки Крим"], available at: http://document. ua/pro-vidi-roslin-sho-pidljagayut-osoblivii-ohoronina-teritor-doc148797.html; http://crimea.gov.ru/textdoc/ua/6/act/1323pr.pdf (accessed 21 February 2017).

Mered'a P. Jr., Kučera J., Marhold K., Senko D., Slovák M., Svitok M., Šingliarová B., Hodálová I. Ecological niche differentiation between tetra- and octoploids of Jacobaea vulgaris. Preslia, 2016a, 88: 113-136.

Mered'a P. Jr., Kučera J., Marhold K., Senko D., Slovák M., Svitok M., Hodálová I. Aktuálne poznatky o karyologickej, genetickej, morfologickej a ekologickej variabilite starčeka Jakubovho (Jacobaea vulgaris, Asteraceae): nový poddruh rozlíšený vo flóre Slovenska [Current knowledge on karyological, genetic, morphological, and ecological variation of Tansy Ragwort (Jacobaea vulgaris, Asteraceae): a new subspecies recognized in the flora of Slovakia]. Bull. Slov. Bot. Spoločn. (Bratislava), 2016b, 38, Suppl. 1: 89-113.

Mosyakin S.L., Fedoronchuk M.M. Vascularplants of Ukraine. A nomenclatural checklist. Kiev, 1999, xxiii + 345 pp., available at: http://dx.doi.org/10.13140/2.1.2985.0409

Nordenstam B. Additions to the genus Jacobaea Mill. (Compositae - Senecioneae). Compositae Newsletter, 2006, 44: $12-13$.
Nordenstam B., Pelser P.B., Kadereit J.W., Watson L.E. Senecioneae. In: Systematics, Evolution and Biogeography of Compositae. Eds V.A. Funk, A. Susanna, T.F. Stuessy, R.J. Bayer, Vienna: Int. Assoc. for Plant Taxonomy, Inst. of Botany, Univ. of Vienna, 2009, pp. 503-521.

Onyshchenko V.A. Habitats of Ukraine according to the EUNIS classification, Kyiv: Phytosociocentre, 2016, 56 pp. [Онищенко В.А. Оселища України за класифікацією $E U N I S$, Київ: Фітосоціоцентр, 2016, 56 с.].

Pelser P.B., Gravendeel B., van der Meijden R. Tackling speciose genera: species composition and phylogenetic position of Senecio sect. Jacobaea (Asteraceae) based on plastid and nrDNA sequences. Amer. J. Bot., 2002, 89: 929-939. doi: 10.3732/ajb.89.6.929

Pelser P.B., Kennedy A.H., Tepe E.J., Shidler J.B., Nordenstam B., Kadereit J.W., Watson L.E. Patterns and causes of incongruence between plastid and nuclear Senecioneae (Asteraceae) phylogenies. Amer. J. Bot., 2010, 97: 856-873. doi: 10.3732/ajb.0900287

Pelser P.B., Nordenstam B., Kadereit J.W., Watson L.E. An ITS phylogeny of tribe Senecioneae (Asteraceae) and a new delimitation of Senecio L. Taxon, 2007, 56: 10771104. doi: $10.2307 / 25065905$

Pelser P.B., Veldkamp J.-F., van der Meijden R. New combinations in Jacobaea Mill. (Asteraceae Senecioneae). Compositae Newsletter, 2006, 44: 1-11.

Privalova L.A. Senecio. In: E.W. Wulff. Flora Taurica, Yalta, 1969, vol. 3, fasc. 3, pp. 225-231. [Привалова Л.А. Senecio. В кн.: Е.В. Вульф. Флора Крыма, Ялта, 1969, т. 3, вып. 3, с. 225-231].

Rudenko M.I. Senecio tauricus. In: Red Data Book of the Republic of Crimea. Plants, algae and fungi. Eds A.V. Yena, A.V. Fateryga, Simferopol: ARIAL, 2015, p. 174. [Руденко М.И. Senecio tauricus. В кн.: Kрасная книга Республики Крым. Растения, водоросли и грибы. Ред. А.В. Ена, А.В. Фатерыга, Симферополь: АРИАЛ, 2015, с. 174].

The Plant List. 2013-onward. Version 1.1. Published on the Internet; http://www.theplantlist.org/ (accessed 16 February 2017).

Thiers B. Index Herbariorum. A global directory of public herbaria and associated staff. New York Botanical Garden's Virtual Herbarium. 2017-onward, available at: http://sweetgum.nybg.org/science/ih (accessed 12 May 2016).

Tzvelev N.N. De plantarum speciebus nonnulis pro parte Europaea URSS novis et raris. In: Novitates Systematicae Plantarum Vascularium, Leningrad: Nauka, 1986, vol. 23, pp. 254-263. [Цвелев Н.Н. О некоторых новых и редких для Европейской части СССР видах растений. В кн.: Новости системат. высш. раст. Л.: Наука, 1986, т. 23, с. 254-263].

Wysk R., Nordenstam B., Kadereit J.W., Westberg E. The identity and geographical distribution of Jacobaea vulgaris subsp. gotlandica, supposedly endemic of Gotland and Öland (Sweden) - the importance of multiple intraspecific samples. Taxon, 2009, 58: 1133-1140.

Yena A.V. Ukr. Bot. J., 2001, 58(6): 667-677. [Ена A.В. Аннотированный чеклист эндемиков флоры Крыма. Укр. бот. журн., 2001, 58(6): 667-677].

Ukr. Bot. J., 2017, 74(4) 
Yena A.V. The phenomenon of floristic endemism and its manifestation in Crimea: Dr. Sci. (Biol.) Diss., Kiev, 2008, 432 рр. [Ена А.В. Феномен флористического эндемизма и его проявления в Крыму: дис. ... д-ра биол. наук, Киев, 2008, 432 с.].

Yena A.V. Senecio tauricus. In: Red Data Book of Ukraine. The Plant Kingdom. Ed. Ya.P. Didukh. Kyiv: Globalconsulting, 2009, p. 339. [Ена A.B. Senecio tauricus. В кн.: Червона книга України. Рослинний світ. Ред. Я.П. Дідух, Київ: Глобалконсалтинг, 2009, 339 с.].

Yena A.V. Spontaneous flora of the Crimean Peninsula, Simferopol: N. Orianda Publ., 2012, 232 pp. [Ена A.B. Природная флора Крымского полуострова, Симферополь: Н. Оріанда, 2012, 232 с.].

Zuyev V.V. Jacobaea. In: Conspectus Florae Rossiae Asiaticae: Plantae Vasculares. Ed. K.S. Baikov, Novosibirsk: Siberian Branch of the Russian Acad. Sci., 2012, pp. 332-333. [Зуев В.В. Jacobaea. В кн.: Конспект флоры Азиатской России: сосудистые растения. Ред. К.С. Байков, Новосибирск: Сиб. отд. РАН, 2012, с. 332-333].

Рекомендує до друку

Надійшла 08.07.2017

Я.П. Дідух

Мосякін С.Л. ${ }^{1}$, Сна А.В. ${ }^{2}$ Jacobaea taurica (Asteraceae), нова комбінація для кримського виду під охороною.

Укр. бот. журн., 2017, 74(4): 303-309.

${ }^{1}$ Інститут ботаніки ім. М.Г. Холодного НАН України вул. Терещенківська, 2, Київ 01004, Україна

${ }^{2}$ Комітет з картування флори Европи та

Українське ботанічне товариство

Senecio tauricus (Asteraceae) був описаний як ендемічний вид, поширений на гірських плато (яйлах) Кримського півострова, що трапляється лише в лугово-степових рослинних угрупованнях. Цей вид був прийнятий в усіх основних флорах, визначниках та флористичних списках, що стосуються регіону; він також включений до чинного видання Червоної книги України (2009) та деяких інших списків охоронюваних видів рослин. Згідно 3 результатами недавніх молекулярно-філогенетичних досліджень, які обгрунтовують виділення декількох родів, які включають таксони, що входили раніше до Senecio sensu lato, пропонується нова номенклатурна комбінація Jacobaea taurica. Також стисло обговорені та узагальнені основні відомості про морфологію, екологічні особливості та поширення J. taurica та деяких споріднених таксонів.

Ключові слова: Senecio, Jacobaea, Asteraceae, номенклатура, систематика, Крим, ендемічний вид
Мосякин С.Л. ${ }^{1}$, Ена А.В. ${ }^{2}$ Jacobaea taurica (Asteraceae), новая комбинация для крымского охраняемого вида. Укр. бот. журн., 2017, 74(4): 303-309.

${ }^{1}$ Інститут ботаники им. Н.Г. Холодного НАН Украины ул. Терещенковская, 2, Киев 01004, Украина

${ }^{2}$ Комитет по картированию флоры Европы и Украинское ботаническое общество

Senecio tauricus (Asteraceae) был описан как эндемический вид, распространенный на горных плато (яйлах) Крымского полуострова, который встречается только в лугово-степных растительных сообществах. Этот вид был принят во всех основных флорах, определителях и флористических списках, касающихся региона. Он также включен в нынешнее издание Красной книги Украины (2009) и в некоторые другие списки охраняемых видов растений. Согласно результатам недавних молекулярно-филогенетических исследований, обосновывающих выделение нескольких родов, включающих таксоны, входившие ранее в Senecio sensu lato, предлагается новая номенклатурная комбинация Jacobaea taurica. Также кратко обсуждены и обобщены основные сведения о морфологии, экологических особенностях и распространении $J$. taurica и некоторых родственных таксонов.

Ключевые слова: Senecio, Jacobaea, Asteraceae, номенклатура, систематика, Крым, эндемический вид 